\title{
Comparative Toxicity of Gasoline and Diesel Engine Emissions
}

JeanClare Seagrave and Joe L. Mauderly Lovelace Respiratory Research Institute

Barbara Zielinska and John Sagebiel Desert Research Institute

Kevin Whitney Southwest Research Institute

Douglas R. Lawson National Renewable Energy Lab

Michael Gurevich U.S. Dept. of Energy 
SAE routinely stocks printed papers for a period of three years following date of publication. Direct your orders to SAE Customer Sales and Satisfaction Department.

Quantity reprint rates can be obtained from the Customer Sales and Satisfaction Department.

To request permission to reprint a technical paper or permission to use copyrighted SAE publications in other works, contact the SAE Publications Group.

This article was prepared as an account of work sponsored by an agency of the United States

Government. Neither the United States Government nor any agency thereof, nor any of their employees, makes any warranty, express or implied, or assumes any legal liability or responsibility for the accuracy, completeness, or usefulness of any information, apparatus, product, or process disclosed, or represents that its use would not infringe privately owned rights. Reference herein to any specific commercial product, process, or service by trade name, trademark, manufacturer, or otherwise does not necessarily constitute or imply its endorsement, recommendation, or favoring by the United States Government or any agency thereof. The views and opinions of authors expressed herein do not necessarily state or reflect those of the United States Government or any agency thereof.

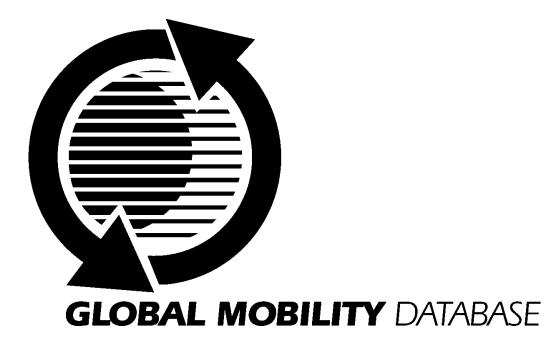

All SAE papers, standards, and selected books are abstracted and indexed in the Global Mobility Database

ISSN 0148-7191

No copyright is asserted in the works of U.S. Government employees.

Positions and opinions advanced in this paper are those of the author(s) and not necessarily those of SAE. The author is solely responsible for the content of the paper. A process is available by which discussions will be printed with the paper if it is published in SAE Transactions. For permission to publish this paper in full or in part, contact the SAE Publications Group.

Persons wishing to submit papers to be considered for presentation or publication through SAE should send the manuscript or a 300 word abstract of a proposed manuscript to: Secretary, Engineering Meetings Board, SAE.

\section{Printed in USA}




\title{
Comparative Toxicity of Gasoline and Diesel Engine Emissions
}

\author{
JeanClare Seagrave and Joe L. Mauderly \\ Lovelace Respiratory Research Institute \\ Barbara Zielinska and John Sagebiel \\ Desert Research Institute \\ Kevin Whitney \\ Southwest Research Institute \\ Douglas R. Lawson \\ National Renewable Energy Lab \\ Michael Gurevich \\ U.S. Dept. of Energy
}

No copyright is asserted in the works of U.S. Government employees

\begin{abstract}
Better information on the comparative toxicity of airborne emissions from different types of engines is needed to guide the development of heavy vehicle engine, fuel, lubricant, and exhaust after-treatment technologies, and to place the health hazards of current heavy vehicle emissions in their proper perspective. To help fill this information gap, samples of vehicle exhaust particles and semi-volatile organic compounds (SVOC) were collected and analyzed. The biological activity of the combined particle-SVOC samples is being tested using standardized toxicity assays. This report provides an update on the design of experiments to test the relative toxicity of engine emissions from various sources.
\end{abstract}

\section{BACKGROUND AND RATIONALE}

There is considerable evidence linking increased levels of air pollution to adverse effects on human health (Thurston, 1996; Goldsmith and Kobzik, 1999; Committee of the Environmental and Occupational Health Assembly of the American Thoracic Society, 1996). Emissions from vehicle engines contribute to air pollution, and the potential health risks from diesel emissions have especially been debated in view of the current concern for fine particles. Most of the past laboratory and epidemiological studies of diesel emissions have focused on lung cancer risk rather than the acute and chronic cardiorespiratory effects attributed to ambient particulate matter (Mauderly, 1999). Most of the available literature on non-cancer effects of engine emissions addresses old-technology diesel engines, primarily focusing on the particulate fraction (Ichinose et al., 1995; Yang et al., 1997; Bayram et al., 1998; Ohtoshi et al., 1998; Murphy et al., 1998a; Takizawa et al., 1999). Changes in gasoline and diesel fuels and spark- and compression-ignition engine control technologies have clearly reduced the total particulate mass emissions, but changes in chemical composition are less certain (Norbeck et al., 1998; Cadle et al., 1999). Gasoline engine emissions also contribute to air pollution, including particles, but there has been little research on their potential health effects. Moreover, the existing laboratory information on the health effects of both diesel and gasoline engine emissions is derived from well-functioning engines, although poorly-functioning engines contribute disproportionately to total on-road vehicle emissions.

The research described in this paper is aimed at developing a better understanding of the relative pulmonary toxicity of particles and semivolatile organic compounds (SVOCs) from relatively low- and high-emitting diesel and gasoline engines. The approach we are taking is to use short-term cell culture (in vitro) and animal (in vivo) assays to compare the toxicities of a matrix of particle and SVOC samples from diesel and gasoline engines, and samples from the heavy-duty and light-duty bores of a traffic tunnel (Ft. McHenry tunnel, Baltimore). The biological assays were selected and standardized in the early stages of the project, based on their ability to rank differences in the toxicity of a range of particles, including diesel soot from two sources, ambient particulate matter, carbon black, silica, oil fly ash, and nickel subsulfide (Nikula et al, 1999, Seagrave and Nikula, 2000). This 
comparative toxicity screening will provide insights into the relative contributions of different engine technologies, low- vs. high-emitting vehicles, and particle vs. SVOC fractions to the health effects of engine emissions. The health risks from human inhalation exposures cannot be directly predicted from these results; however, comparisons between the results obtained from these types of assays (Nikula et al., 1995; Seagrave and Nikula, 2000, and unpublished data) and from inhalation exposures of animals (Nikula et al., 1995) suggest that the relative ranking of the pulmonary toxicities of the samples should predict their relative toxicities by inhalation. The study will provide direct comparisons that do not currently exist, and will help determine if more complex and expensive inhalation studies are warranted.

This research is being conducted for the Office of Heavy Vehicle Technologies, U.S. Department of Energy, and is a collaborative effort among the Lovelace Respiratory Research Institute (health assays), the National Renewable Energy Laboratory (project management), Desert Research Institute (sample collection, preparation, and analysis), and Southwest Research Institute (sample collection). In addition, genotoxicity measurements on selected exhaust samples are being performed at $\mathrm{NIOSH}$, particle morphology is being characterized at Oak Ridge National Laboratory, and comprehensive chemical analysis of the exhaust particulate matter is being conducted at University of Dayton Research Institute.

\section{EXPERIMENTAL DESIGN AND METHODS}

TEST MATERIALS - The materials to be tested include SVOC's and particulate matter from several sources. Airborne material was collected from the Ft. McHenry tunnels (bore 3, $0.4 \%$ heavy diesel vehicles and bore 4 , $34.5 \%$ heavy diesel vehicles) and from the intake of ambient air for tunnel ventilation. These samples were size-selected with a $50 \%$ cut-off of $2.5 \mu \mathrm{m}$ mean aerodynamic diameter. Chassis dynamometer-generated total particulate and SVOC exhaust samples were collected at $72^{\circ} \mathrm{F}$ nominal from average gasoline vehicles, a "black smoker" gasoline vehicle, a "white smoker" gasoline vehicle, current technology diesel vehicles, and a high-emitter diesel vehicle. Samples from the average gasoline and current technology diesel vehicles were also collected at $30^{\circ} \mathrm{F}$. Separate SVOC samples will also be tested from the average gasoline and current technology diesel vehicles run at $72^{\circ} \mathrm{F}$. Dynamometer samples of exhaust particulate matter and SVOCs from advanced technology gasoline and diesel vehicles have also been collected as part of the overall study, but their mass emission rates are so low that it was not practical to perform the toxicity tests outlined in this report.

To provide an internal control for each set of samples tested, a standard diesel soot (National Institute of Standards Diesel Particulate Standard 2975 (Hughes et al., 1997) is included in each experiment. This sample is prepared and stored as a suspension in acetone to parallel the physical characteristics of the test samples. Test particulate materials are collected on filters and extracted by sonication in acetone. SVOC's are collected onto polyurethane foam/polystyrene/divinylbenzene polymer (PUF/XAD) from material passing through the filters. The SVOC's are also extracted into acetone. Both fractions are stored in the dark at $-20^{\circ} \mathrm{C}$. Extraction controls consisting of filter and PUF/XAD matrix extracted into acetone without exposure to exhaust materials are included in each experiment as negative controls. The particulate fraction and SVOC's for each test material are re-combined in the relative concentrations present in the original volume of filtered air. The combined sample is then suspended in tissue culture medium (for in vitro exposures) or physiological saline (for intratracheal instillation) with $0.01 \%$ Tween-80, a nonionic surfactant to aid in the dispersion of the particles and organics. The final concentration of acetone does not exceed $1.5 \%$, and neither the Tween-80 nor acetone at these concentrations causes effects themselves or affects responses to a positive control particle, silica. The samples are sonicated to disperse the particles and form an emulsion of the SVOC's.

ASSAYS - The four types of assays performed to evaluate relative toxicity of include a) in vitro exposure of a cultured human alveolar type II cell line (Finkelstein, 1990; Stringer et al., 1996; Finkelstein et al.,1997; Seagrave and Nikula, 2000); b) in vitro exposure of primary rat alveolar macrophages (Driscoll and Maurer, 1991; Becker et al., 1996; Goldsmith et al., 1997; Yang et al., 1997); c) in vivo exposure of Fischer 344 rats by intratracheal instillation (Driscoll et al., 1995; Ichinose et al., 1995; Li et al., 1997; Osier and Oberdorster, 1997; Murphy et al., 1998); and d) mutagenicity testing by the Ames method (Hughes et al., 1997). The mutagenicity assays have not yet been conducted and will not be discussed in this paper.

Alveolar type II cells are important targets for inhaled toxicants (Finkelstein, 1990; Wallaert et al., 1996). The cultured cell line (A549 cells) represents a convenient, standardized bioassay system with several discrete types of responses to physical and chemical toxicants (Seagrave and Nikula, 2000). Cells are grown adherent to 96well tissue culture plates in RPMI 1640 tissue culture medium supplemented with antibiotics (penicillin and streptomycin), glutamine, and fetal bovine serum. This format allows for simultaneous testing of a wide range of concentrations of the test materials $\left(0.1-1000 \mu \mathrm{g} / \mathrm{cm}^{2}\right)$. After overnight incubation with the test materials, the tissue culture medium is analyzed for release of lactate dehydrogenase (LDH, a cytoplasmic enzyme whose release indicates damage to the cell membrane and loss of viability), interleukin-8 (IL-8, a cytokine involved in signaling inflammatory responses, particularly recruitment of neutrophils, which is produced and secreted by these epithelial cells in response to injury (Finkelstein, 1990; Kunkle et al., 1991; Stringer et al., 1996; Finkelstein et al., 1997)), and alkaline phosphatase (APase, an enzyme whose physiological function is still unknown, but release 
of which by epithelial cells (Henderson et al., 1995) has been shown to correlate with either proliferative or fibrogenic responses in the intact lung (Capelli et al., 1997; Cobben et al., 1999; Bhalla et al., 1999)). In addition, the cells remaining attached to the tissue culture substrate are stained and measured to provide a second indication of viability.

Alveolar macrophages are the primary cell type involved in clearance of inhaled particulate materials. Because there are no cell lines that represent human alveolar macrophages, the bioassays use macrophages harvested from the lungs of untreated Fischer 344 rats. These cells are allowed to attach to 96-well tissue culture plates and are exposed to the test materials similar to the A549 cells. To assess acute cell damage caused by the test materials, $\mathrm{LDH}$ release is measured in the medium as for A549 cells. A key cytokine released by stimulated macrophages is Tumor Necrosis Factor $\alpha$ (TNF $\alpha$ ), which is involved in recruitment of additional inflammatory cells, alterations in epithelial and endothelial permeability, and pyrogenic responses. LDH and TNF $\alpha$ are measured in the tissue culture medium after overnight incubation. A second type of response of macrophages to particulate stimuli is the production of reactive oxygen species, especially superoxide $\left(\mathrm{O}_{2}^{-}\right)$and peroxide $\left(\mathrm{HOO}^{\circ}\right)$. These free radicals are important in killing bacteria, but excessive production may be damaging to the surrounding tissues. To measure the macrophage production of these species, the test materials are added to the macrophages. Production of $\mathrm{O}_{2}{ }^{-}$is measured by the change in absorbance of cytochrome $\mathrm{c}$ as it is reduced by the $\mathrm{O}_{2}^{-}$, and production of $\mathrm{HOO}^{\circ}$ is measured by horseradish peroxidase-catalyzed oxidation of luminol with release of light.

The in vitro techniques described in the preceding section provide useful information on the responses of individual cell types (type II cells and macrophages) to toxicants and have the advantage of rapid and relatively inexpensive screening at a wide range of doses of the materials. However, toxicity in the intact animal may depend on complex interactions between many cell types. Screening by intratracheal instillation of the test materials therefore may provide additional information. Following the in vitro screening, selected doses $(2,1$ and $0.3 \mathrm{mg} / \mathrm{rat}$ for the samples tested to date) of the test materials are instilled into the lungs of male Fischer 344 rats by intratracheal cannulation under brief halothane anesthesia. Five animals per dose are then euthanized at 4 hours, 12 hours, 24 hours, 1 week and 1 month after the instillation. The lungs are removed, weighed, and examined for gross pathological alterations. The right apical lobe is preserved by flash freezing in liquid nitrogen for future analysis of cytokines or oxidative stress markers. The left bronchus is clamped to allow instillation and recovery of physiological saline into the rest of the right lung. This material is collected and analyzed for the total number of leukocytes and differential cell counting of the types of leukocytes. At all times, the cell-free superna- tant is analyzed for LDH, $\beta$-glucuronidase (an enzyme released from activated macrophages), alkaline phosphatase, and total protein. At the early times (4, 12, and 24 hours), aliquots are frozen for subsequent analysis of the cytokines TNF $\alpha$ and MIP-2 (Macrophage Inflammatory Protein 2, a rat cytokine with functions similar to human IL-8) and for protein carbonyls produced by oxidant stress. Total and oxidized glutathione is measured at 4 and 12 hours to provide additional information on oxidant stress. At the later times (24 hours, 1 week, and 1 month), the production of $\mathrm{O}_{2}^{-}$and $\mathrm{HOO}^{\circ}$ by the macrophages is measured as described above. In these assays, the macrophages are analyzed under resting conditions (i.e., stimulated only by the in vivo exposure to particles) and during stimulation with opsonized zymosan (a surrogate for bacteria).

The toxicity testing of the first (tunnel) samples was recently begun at the time of this writing; thus few data had been obtained and no conclusions could yet be drawn.

\section{DISCUSSION}

The few data obtained at the time of this writing do not allow speculation regarding the final results. However, the initial results suggest that both the particle and SVOC fractions have biological activity, and that comparisons between the two fractions will be of interest, as well as comparisons among engines and emission rates. The laboratory assays described above will yield data on the comparative toxicities of the samples per unit of sample mass. These results will be combined with data describing the sampling conditions to develop estimates of the comparative toxicities of the different emissions per unit of use (e.g., per brake-horsepower/hr, per mile, etc.). These studies will provide a foundation for understanding the relative toxicities of the different types of exhaust materials and will help determine the need for and direction of additional comparisons.

\section{ACKNOWLEDGMENTS}

The authors gratefully acknowledge useful discussions with Dr. Kristen Nikula and the outstanding technical assistance of Jennifer Berger.

\section{REFERENCES}

1. Bayram, H., Devalia, J.L., Sapsford, R.J., Ohtoshi, T., Miyabara, Y., Sagai, M. and Davies, R.J.. "The effect of diesel exhaust particles on cell function and release of inflammatory mediators from human bronchial epithelial cells in vitro,"

Am. J. Respir. Cell Mol. Biol. 18: 441-448, 1998.

2. Becker, S., Soukup, J.M., Gilmour, M.I. and Devlin, R.B.. "Stimulation of human and rat alveolar macrophages by urban air particulates: effects on oxidant radical generation and cytokine production," Toxicol. Appl. Pharmacol. 141:637-648, 1996. 
3. Bhalla, D.K., Gupta, S.K. and Reinhart, P.G. "Alteration of epithelial integrity, alkaline phosphatase activity, and fibronectin expression in lungs of rats exposed to ozone," J. Toxicol. Environ. Health 57:329-343, 1999.

4. Cadle, S.H., Mulawa, P.A., Hunsanger, E.C., Nelson, K., Ragazzi, R.A., Barrett, R., Gallagher, G.L., Lawson, D.R., Knapp, K.T., Snow, R. "Composition of light-duty motor vehicle exhaust particulate matter in the Denver, Colorado area," Environ. Sci. Technol. 33:2328-2339, 1999.

5. Capelli, A., Lusuardi, M., Cerutti, C.G. and Donner, C.F. "Lung alkaline phosphatase as a marker of fibrosis in chronic interstitial disorders," Am. J. Respir. Crit. Care Med. 155:249-253, 1997.

6. Cobben, N.A., Drent, M., Jacobs, J.A., Schmitz, M.P., Mulder, P.G., Henderson, R.F., Wouters, E.F. and van Dieijen-Visser, M.P. "Relationship between enzymatic markers of pulmonary cell damage and cellular profile: a study in bronchoalveolar lavage fluid," Exp. Lung Res. 25:99-111, 1999.

7. Committee of the Environmental and Occupational Health Assembly of the American Thoracic Society. "Health effects of outdoor air pollution," Am. J. Respir. Crit. Care Med. 153:3-50. 1996.

8. Driscoll, K.E., Hassenbein, D.G., Carter, J.M., Kunkel, S.L., Quinlan, T.R. and Mossman, B.T. "TNF alpha and increased chemokine expression in rat lung after particle exposure," Toxicol. Lett. 8283:483-9:483-489, 1995.

9. Driscoll, K.E. and Maurer, J.K. "Cytokine and growth factor release by alveolar macrophages: potential biomarkers of pulmonary toxicity," Toxicol. Pathol. 19:398-405, 1991.

10. Finkelstein, J.N. "Physiologic and toxicologic responses of alveolar type II cells," Toxicology 60:4152. 1990.

11. Finkelstein, J.N., Johnston, C., Barrett, T. and Oberdorster, G. "Particulate-cell interactions and pulmonary cytokine expression," Environ. Health Perspect. 105 Suppl 5:1179-82:1179-1182, 1997.

12. Goldsmith, C.A., Frevert, C., Imrich, A., Sioutas, C. and Kobzik, L. "Alveolar macrophage interaction with air pollution particulates," Environ. Health Perspect. 105S:1191-1195. 1997.

13. Goldsmith, C.A. and Kobzik, L. "Particulate air pollution and asthma: a review of epidemiological and biological studies," Rev. Environ. Health 14:121-134. 1999.

14. Henderson, R.F., Scott, G.G. and Waide, J.J. "Source of alkaline phosphatase activity in epithelial lining fluid of normal and injured F344 rat lungs," Toxicol Appl. Pharmacol. 134:170-174, 1995.

15. Hughes, T.J., Lewtas, J. and Claxton, L.D. "Development of a standard reference material for diesel mutagenicity in the Salmonella plate incorporation assay," Mutat. Res. 391:243-258, 1997.
16. Ichinose, T., Furuyama, A. and Sagai, M. "Biological effects of diesel exhaust particles (DEP). II. Acute toxicity of DEP introduced into lung by intratracheal instillation," Toxicology 99:153-167, 1995.

17. Kunkel, S.L., Standiford, T., Kasahara, K. and Strieter, R.M. "Interleukin-8 (IL-8): the major neutrophil chemotactic factor in the lung," Exp. Lung Res. 17:17-23, 1991.

18. Li, X.Y., Gilmour, P.S., Donaldson, K. and MacNee, W. "In vivo and in vitro proinflammatory effects of particulate air pollution (PM10)," Environ. Health Perspect. 105 Suppl 5: 1279-1283, 1997.

19. Mauderly, J. L.: "Diesel Exhaust". In: Environmental Toxicants: Human Exposures and Their Health Effects, Second Edition., M. Lippmann, ed., Wiley, pp. 193-241, 1999

20. Murphy, S.A., BeruBe, K.A., Pooley, F.D. and Richards, R.J. "The response of lung epithelium to well characterised fine particles," Life Sci. 62:17891799. 1998.

21. Nikula, K.J., Snipes, M.B., Barr, E.B., Griffith, W.C., Henderson, R.F. and Mauderly, J.L.. "Comparative pulmonary toxicities and carcinogenicities of chronically inhaled diesel exhaust and carbon black in F344 rats," Fundam. Appl. Toxicol. 25:80-94, 1995.

22. Nikula, K. J., Finch, G. L., Westhouse, R. A., Seagrave, J., Mauderly, J. L., Lawson, D. R., and Gurevich, M. "Progress is understanding the toxicity of gasoline and diesel engine exhaust emissions", SAE Technical Paper Series, No. 1999-01-2250, Society of Automotive Engineers, pp. 1-16, 1999.

23. Truex, T.J., Norbeck, J. M., Smith, M.R., Arey, J., Kado, N., Okamoto, B., Kiefer, K., Kuzmicky, P., Holcomb, I. Evaluation of Factors that Affect Diesel Exhaust Toxicity, Final Report to California Air Resources Board, Contract No. 94-312, Center for Environmental Research and Technology, University of California, Riverside, July 24, 1998

24. Ohtoshi, T., Takizawa, H., Okazaki, H., Kawasaki, S., Takeuchi, N., Ohta, K. and Ito, K. "Diesel exhaust particles stimulate human airway epithelial cells to produce cytokines relevant to airway inflammation in vitro," J. Allergy Clin. Immunol. 101:778-785, 1998.

25. Osier, M. and Oberdorster, G. "Intratracheal inhalation vs intratracheal instillation: differences in particle effects," Fundam. Appl. Toxicol. 40:220-227, 1997.

26. Seagrave, JC. and Nikula, K.J. "Multiple modes of responses to air pollution particulate materials in A549 alveolar type II cells," Inhal. Toxicol. (In Press, 2000).

27. Stringer, B., Imrich, A. and Kobzik, L. "Lung epithelial cell (A549) interaction with unopsonized environmental particulates: quantitation of particle-specific binding and IL-8 production,"

Exp. Lung Res. 22:495-508, 1996. 
28. Takizawa, H., Ohtoshi, T., Kawasaki, S., Kohyama, T., Desaki, M., Kasama, T., Kobayashi, K., Nakahara, K., Yamamoto, K., Matsushima, K. and Kudoh, S. "Diesel exhaust particles induce NF-kappa B activation in human bronchial epithelial cells in vitro: importance in cytokine transcription," J. Immunol. 162:47054711, 1999.

29. Thurston, G.D. "A critical review of PM10-mortality time-series studies," J. Expo. Anal. Environ. Epidemiol. 6:3-21. 1996

30. Wallaert, B., Gosset, P., Boitelle, A. and Tonnel, A.B. "In vitro assessment of environmental toxicology using alveolar cells as target,"

Cell Biol. Toxicol. 12:251-256. 1996.

31. Yang, H.M., Ma, J.Y., Castranova, V. and Ma, J.K. "Effects of diesel exhaust particles on the release of interleukin-1 and tumor necrosis factor-alpha from rat alveolar macrophages,"

Exp. Lung Res. 23:269-284. 1997.

\section{CONTACT}

JeanClare Seagrave

Lovelace Respiratory Research Institute

PO Box 5890

Albuquerque, NM 87185

Phone: (505) 845-1159

Fax: (505) 845-1198

E-mail: jseagrav@Irri.org 